\title{
War, Peace, Conflict Resolution in Ex FATA Pakistan after 9/11: A Situation Analysis 2020
}

\author{
Shabir Zaman', Mukammil shah Yousafzai ${ }^{2}$ \\ Program Director/Research officer/ex lecturer, Student of International Relation, Abdul Wali Khan University \\ Pakistan
}

\begin{abstract}
Peace and harmony in Ex FATA Pakistan are essential for peace, development and prosperity in Pakistan and Afghanistan. Ex FATA Pakistan is one of the areas where most of the violence is in the two countries. Allegedly, it is a center of militancy and is meant to hurt the people of both countries. And as a result, worries of people living in Ex FATA Pakistan are also increasing, leading to heavy searches by Pakistani forces and security operations, as well as cross-border drone strikes and other attacks. -

The current situation in Ex FATA Pakistan guarantees an in-depth analysis of the issue. The current paper intends to explore the root causes of the problem and propose remedial measures. The research is divided into five parts: the first part includes a brief introduction to EX FATA PAKISTAN. The second and third part, respectively, contains surveys of the fundamental and proximate causes of militancy in EX FATA PAKISTAN. The fourth section contains some recommendations / policy guidelines, and more. The fifth part is the closing part.

The Ex Federally Administered Tribal Areas (FATA), comprised of 7 agencies and 6 tribal areas, covers an area of 27220 square kilometers with a population of 3.15 million people. Until the dawn of the 21st century, FATA was one of the peaceful areas of the country when this situation took a new turn in the history of the area. After 9/11, Pakistani policies caused great resentment among the people of the area, which eventually led to the rise of militancy. The ongoing insurgency has taken the lives of more than 50,000 people in Pakistan so far, and since 2001 it has lost more than $\$ 100$ billion.
\end{abstract}

Keywords Peace, development, security operations, prosperity, militancy, cross-border drone strikes, after $9 / 11$ 